\title{
Environmental Regulation of Human Health Nutrients(Ascorbic Acid, $\beta$-Carotene, and Folic Acid) in Fruits and Vegetables
}

\author{
Gene E. Lester \\ Kika de la Garza Subtropical Agricultural Research Center, Agricultural Research Service, U.S. Department of \\ Agriculture, 2413 East Highway 83, Building 200, Weslaco, TX 78596
}

Adiet rich in fruits and vegetables provides an abundance of human health compounds. These compounds synthesized originally by plants or accumulated by plants and which are known to have a multitude of human health (wellness) benefits are called phytonutrients. Three of the most important human health phytonutrients are vitamins $(\mathrm{A}=\beta$-carotene, $\mathrm{B} 9=$ folic acid, and $\mathrm{C}=$ ascorbic acid) that are abundant and easily derived from fruits and vegetables (Craig and Beck, 1999). As such, this illustrative review will focus on ascorbic acid, $\beta$-carotene, and folic acid, and how environmental factors affect their accumulation in plants.

\section{PHYTONUTRIENTS}

$\beta$-Carotene (pro-vitamin A). VitaminA, per se, is not available from plants, it is synthesized in the body from ingested plants containing carotenoids, e.g., $\beta$-carotene (pro-vitamin A). $\beta$-carotene, a powerful antioxidant, is a fat-soluble precursor to vitamin A (Kiokias and Gordon, 2004) discovered in carrots in 1831 (Gross, 1991). The richest plant sources of $\beta$-carotene can be found in apricot (Prunis armeniaca L.), broccoli (Brassica oleracea L. Italica group ), carrot (Daucus carota L.), kale (Brassica oleracea L. var. acephala), mango (Mangifera indica L.), muskmelon (Cucumis melo L.), nectarine (Pruuis persica var. nucipersica (Suchow) C.K. Schneid.), orange (Citrus sinensis (L.) Osbeck.), parsley (Petroselinum crispum), papaya (Carica papaya L.), peach (Prunus persica (L.) Batsch), spinach (Spinacia oleracea L.), sweet basil (Ocimum basilicum L.) and sweet potato (Ipomoea batatas (L.) Lam) (www.nal.usda. gov/fnic/foodcomp. $\beta$-Carotene helps the immune system target and destroy cancer cells (Nkondjock and Ghadirian, 2004); reduces the risk of heart disease, stroke, cardiovascular disease, chronic fatigue syndrome, psoriasis, skin cancer, and lupus (Hyson, 2002); and is necessary for human-eye light reception, prevention of night blindness, and cataracts (Bartley and Scolnik, 1995).

Ascorbic acid (vitamin C). Ascorbic acid was first discovered in citrus in 1928, and is a water-soluble antioxidant (Lavine, 1986). The richest plant sources for vitamin $\mathrm{C}$ (ascorbic acid) can be found in broccoli, all citrus (Citrus sp.), muskmelon, pepper (Capsicum

This article was funded by the USDA-ARS under CRIS No. 6204-43000-014-00D. Reprint requests should be addressed; e-mail glester@weslaco.ars. usda.gov. The author wishes to thank Penny PerkinsVeasie and Donald Makus for their critical reviews of this manuscript. annuum L.), pineapple [Ananas comosus (L.) Merrill], potato (Solanum tuberosum L.), spinach, strawberry (Fragaria $\times$ ananassa Duch.), and tomato (Lycopersicum esculentum Mill.). Ascorbic acid is critical in maintaining a healthy immune system, reducing the severity of colds by preventing secondary viral or bacterial infections, protecting against damage by reducing free radicals (Larsen, 1997), and in the prevention of cardiovascular disease (Eichholzer et al., 2001).

Folic acid (vitamin B9). Folic acid was first isolated in 1941 from spinach and characterized as B9, a water-soluble vitamin and a member of the vitamin B complex (Cossins, 2000). The richest plant sources for folic acid can be found in asparagus (Asparagus officinalis L.), broccoli, butterhead lettuce (Latuca sativa L. var. capitata), chickpea (Cicer arietinum L.), dry beans (Phaseolus vulgaris L.), lentils (Lens culinaris Medik.), and spinach. Other members of the B complex are B1 (thiamine), B2 (riboflavin), B3 (niacin), B5 (pantothenic acid), B6 (pyridoxine), B12 (cyanocobalamin), and biotin (vitamin $\mathrm{H}$ ). Folic acid helps in the transport of amino acids to the appropriate location in protein chain creation (Kelly, 1998), is involved in methylation of amino acids, DNA, and RNA(Lucock at al., 1996; Ma etal., 1997); regenerates methionine from homocystine, a compound contributing to cardiovascular disease (Laclerc et al., 1998); is involved in cell division, differentiation, and regulation
(Henning et al., 1997); and regulates the central nervous system, mood, sleep, and appetite (Bottiglieri et al., 2000). Folate deficiencies in women of child bearing age are highly linked with neural tube defects and spina bifida in newborn infants. This is both a first and third world problem (Scott et al., 2000).

Increasing the concentration of these and other human wellness compounds in fruits and vegetables is the current challenge to plant scientists. Traditionally, plant breeding and molecular genetics (genomics) are considered the only approaches to improving fruit and vegetable nutrient quality. However, it has been shown that produce growers, using specific commercial cultivars, can increase as much as 5-fold the concentration of some human wellness compounds by simple soil type selection (Lester and Eischen, 1996; Lester and Crosby, 2002).

\section{ENVIRONMENTAL FACTORS: CLIMATIC, CULTURAL, PESTS AND POLLUTION (AIR), AND FRUIT OR VEGETABLE SIZE}

The qualitative make-up of all fruits and vegetables is highly regulated by genetics (Stevens, 1974). Once a cultivar is growing, the environment imparts a major influence on the concentration of all phytonutrients (Mozafar, 1994). It is with this environmental effect in mind that we as plant physiologists, horticulturists,

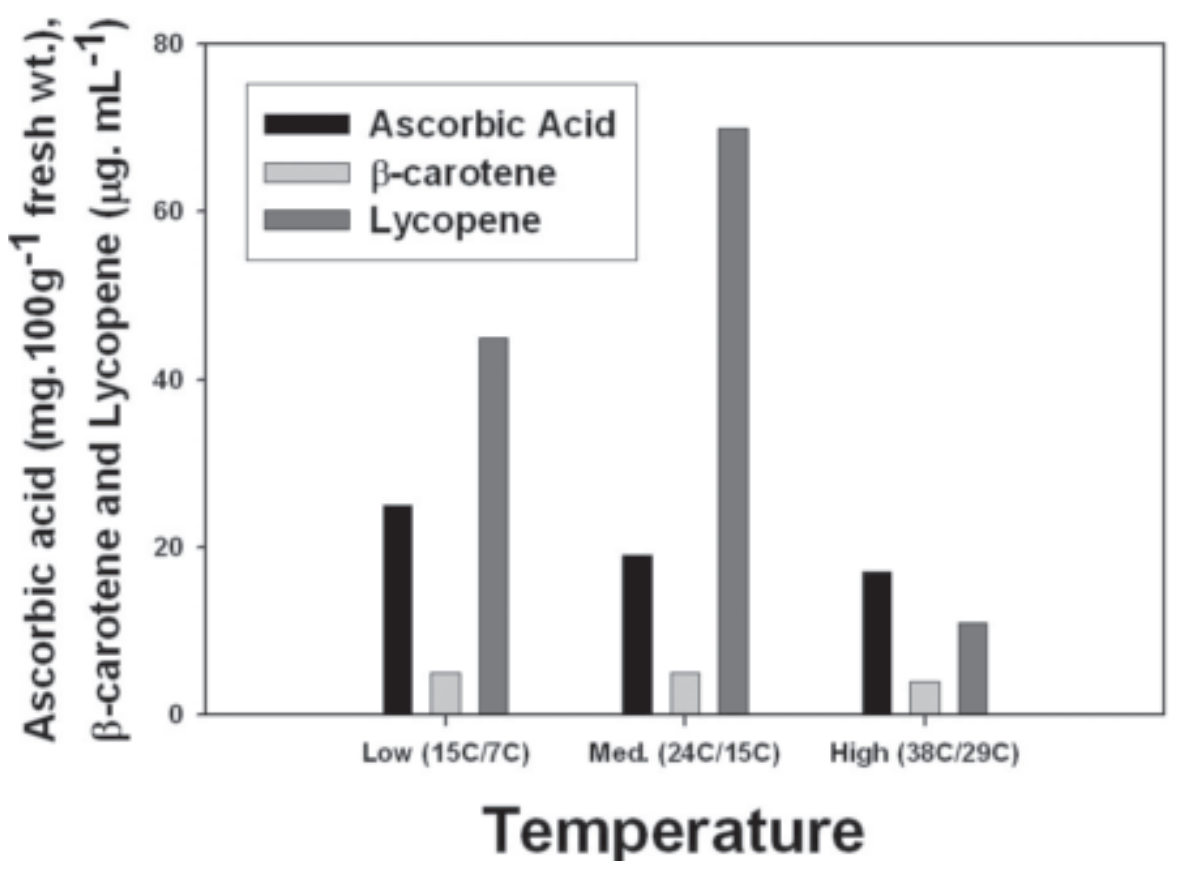

Fig. 1. Ascorbic acid, $\beta$-carotene, and lycopene content of vine ripened tomato 'John Baer' fruit grown at low vs. high day/night temperatures (Sayre et al., 1953). 
and growers can influence the phytonutrient levels in fruits and vegetables, by considering where and when we grow specific produce. This review will provide an illustrative overview of how environmental factors including temperature, light intensity, light quality, altitude, soil $\mathrm{pH}$, soil type, fertilizers, production practices

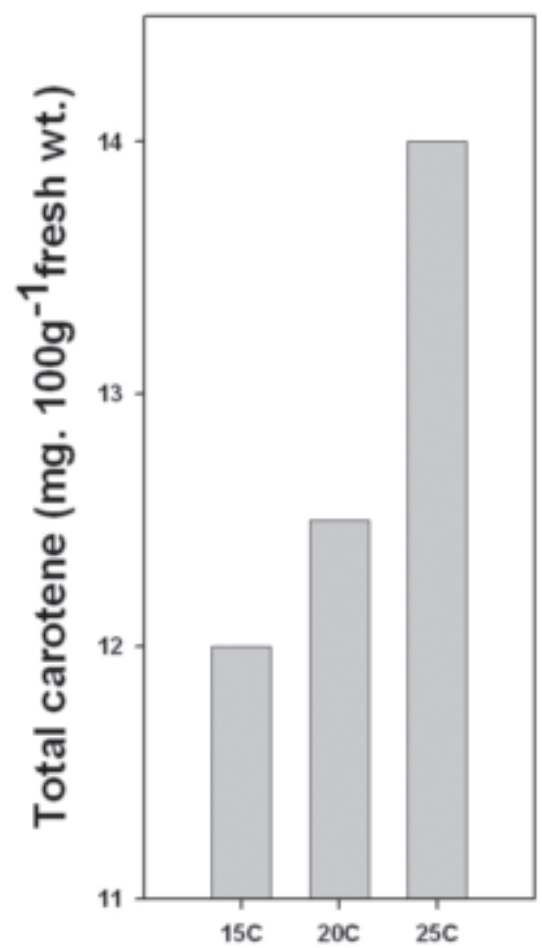

(organic versus conventional, and field versus greenhouse), irrigation, pests, and pollution (primarily air pollution), and fruit or vegetable size affect the concentration of ascorbic acid, $\beta$-carotene, and/or folic acid in harvested fresh produce. The comprehensive guiding information source for this review was Mozafar (1994).

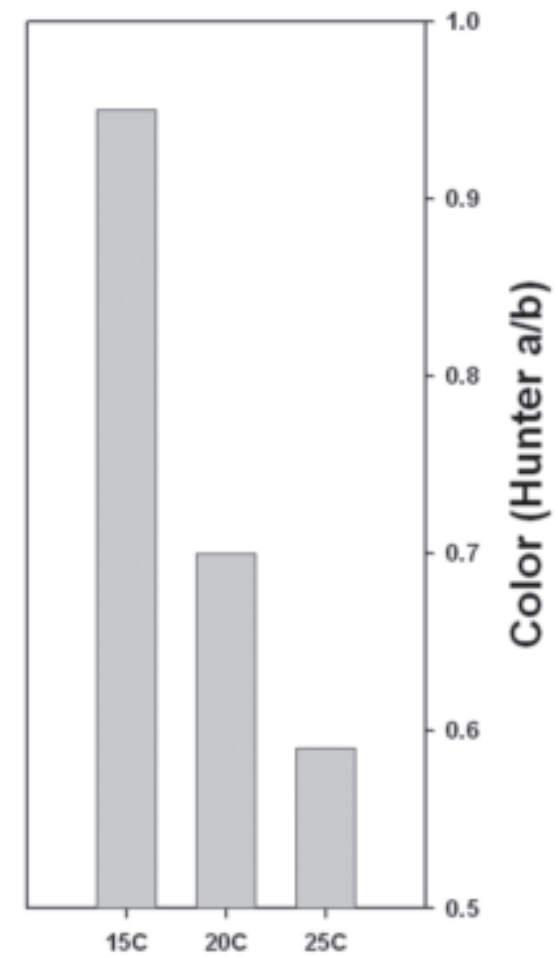

Temperature

Fig. 2. Effects of carrot root temperatures 2 weeks before harvest on total carotene and root color (Bradley et al., 1967).
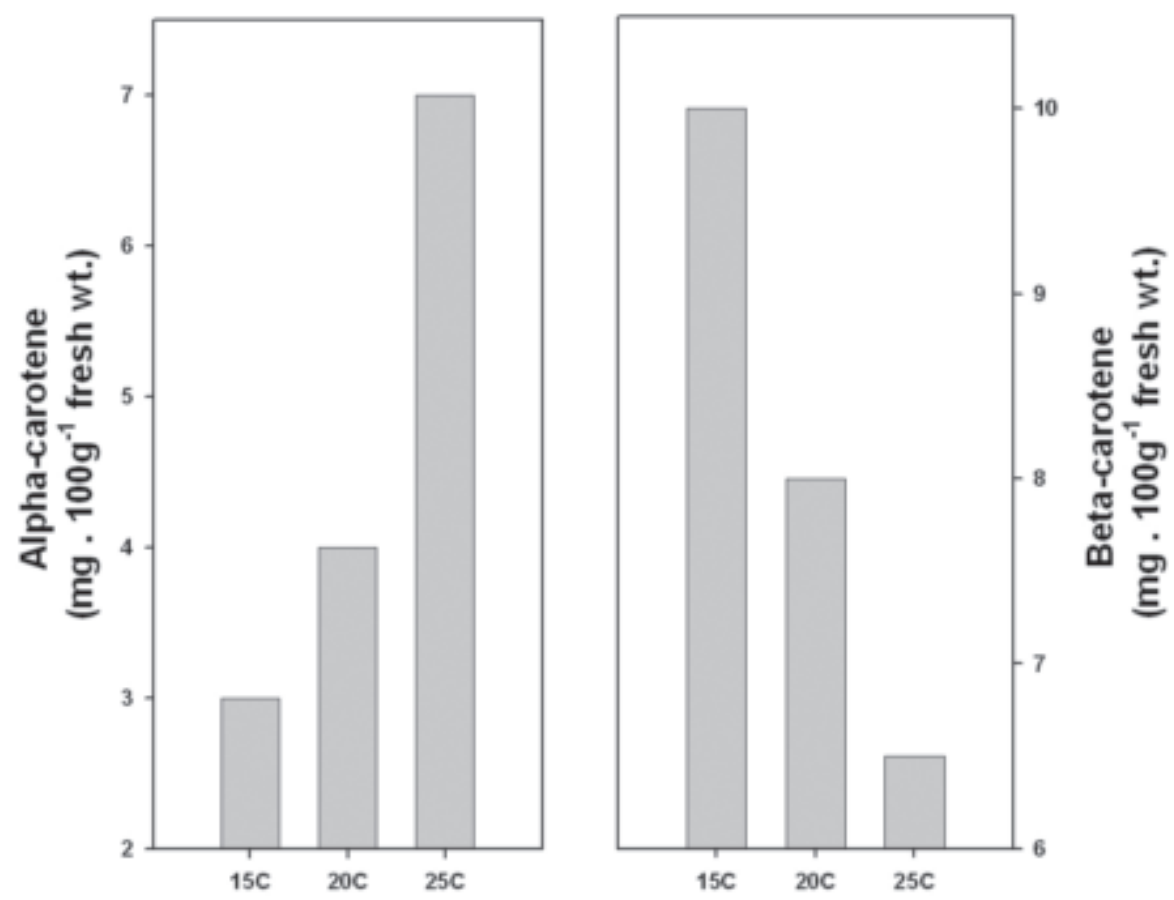

Temperature

Fig. 3. Effects of carrot root temperatures 2 weeks before harvest on $\alpha$-carotene and $\beta$-carotene (Bradley et al., 1967).
Other factors influencing phytonutrients such as genotypic variation (Harris, 1975; Stevens, 1974), maturity at harvest, harvesting method, and postharvest handling (Kader, 1988; Kalt, 2005; Lee and Kader, 2000) have been reviewed and will not be discussed herein.

Temperature. Vine ripened tomato fruit grown at low versus medium, or high day/ night temperatures have altered concentrations of ascorbic acid and carotenoids (Fig. 1) (Sayre et al., 1953). Ascorbic acid declines with increasing temperature, while lycopene, the principal carotenoid (coloring agent) in tomatoes, increases with an increase from low to medium temperatures, then drastically declines as temperatures increase from medium to high. In a similar study measuring $\alpha$ - and $\beta$-carotenes in carrot roots exposed to 15,20 , or $25^{\circ} \mathrm{C}$ temperatures 2 weeks before harvest, a dramatic difference in the synthesis of the two carotenoids was shown (Figs. 2 and 3, Bradley et al., 1967). Total carotenoids increased with an increase in temperature, but the orange color decreased (Fig. 2) (Bradley et al., 1967). $\alpha$-carotene increased with increasing temperatures, influencing the overall increase in total carotenoids concentration, whereas $\beta$-carotene decreased with increasing temperatures, resulting in decreased orange carrot root color. The overall general effects of temperature on ascorbic acid and $\beta$-carotene content in fruits and vegetables from these examples and others (Mozafar, 1994) can be summarized as follows: 1) most leafy vegetables and temperate fruits, grown at low versus high $\left(30^{\circ} \mathrm{C}\right)$ temperatures will have higher ascorbic acid concentrations; 2) an increase or decrease in air temperature of $4{ }^{\circ} \mathrm{C}, 4$ to $5 \mathrm{~d}$ before harvest, has the greatest impact on postharvest ascorbic acid concentrations; 3) low temperatures increase ascorbic acid concentrations in produce, because degradation is reduced; and 4) temperature regulation of carotenoids is crop specific. In cool season crops such as carrot, maximum $\beta$-carotene synthesis occurs at 15 to $21^{\circ} \mathrm{C}$. In warm season crops such as guava (Psidium guajava L.), papaya, mango, and melon, optimum $\beta$-carotene synthesis occurs at $30{ }^{\circ} \mathrm{C}$. Carotenoid synthesis in tomato is even more temperature dependent; maximum lycopene synthesis occurs at 25 to $30^{\circ} \mathrm{C}$ and is inhibited above $32{ }^{\circ} \mathrm{C}$ (Tomes, 1963). In watermelon (Citrullus lanatus (Thunb.) Matsumura and Nakai), lycopene synthesis is inhibited above $37{ }^{\circ} \mathrm{C}$ (Vogele, 1937).

Light. Light intensity and light quality are extremely influential in regulating fruit and vegetable vitamin content. Mustard greens grown under full sunlight versus $50 \%$ sunlight were significantly lower in ascorbic acid concentration, and significantly higher in total carotene and total chlorophyll concentrations (Fig. 4) (Makus and Lester, 2002). Findings from this mustard-leaf light study demonstrated that 1 ) reduced light intensity reduces the synthesis of glucose, the starting molecule in ascorbic acid biosynthesis, and the ascorbic acid concentration declined; 2) reducing light intensity reduces leaf temperature, which is favorable for $\beta$-carotene synthesis; 3 ) increased $\beta$-carotene content 
increases the protection of chlorophyll from photo-bleaching, thus increasing chlorophyll concentration; and 4) light intensity appears to have little influence on folic acid content in mustard greens. Several studies on a variety of fruits and vegetables such as apple (Zhi-Qiang etal., 1999), broccoli(Krumbien and Schonhof, 1999), citrus (Izumi et al., 1992), green bean leaves (Schmitz-Eiberger and Noga, 2001), grape (Uhlig-Birgit, 1998), pepper (Simkin et al., 2003), and spinach (Nakamoto et al., 1998) have examined the effect of light qual-
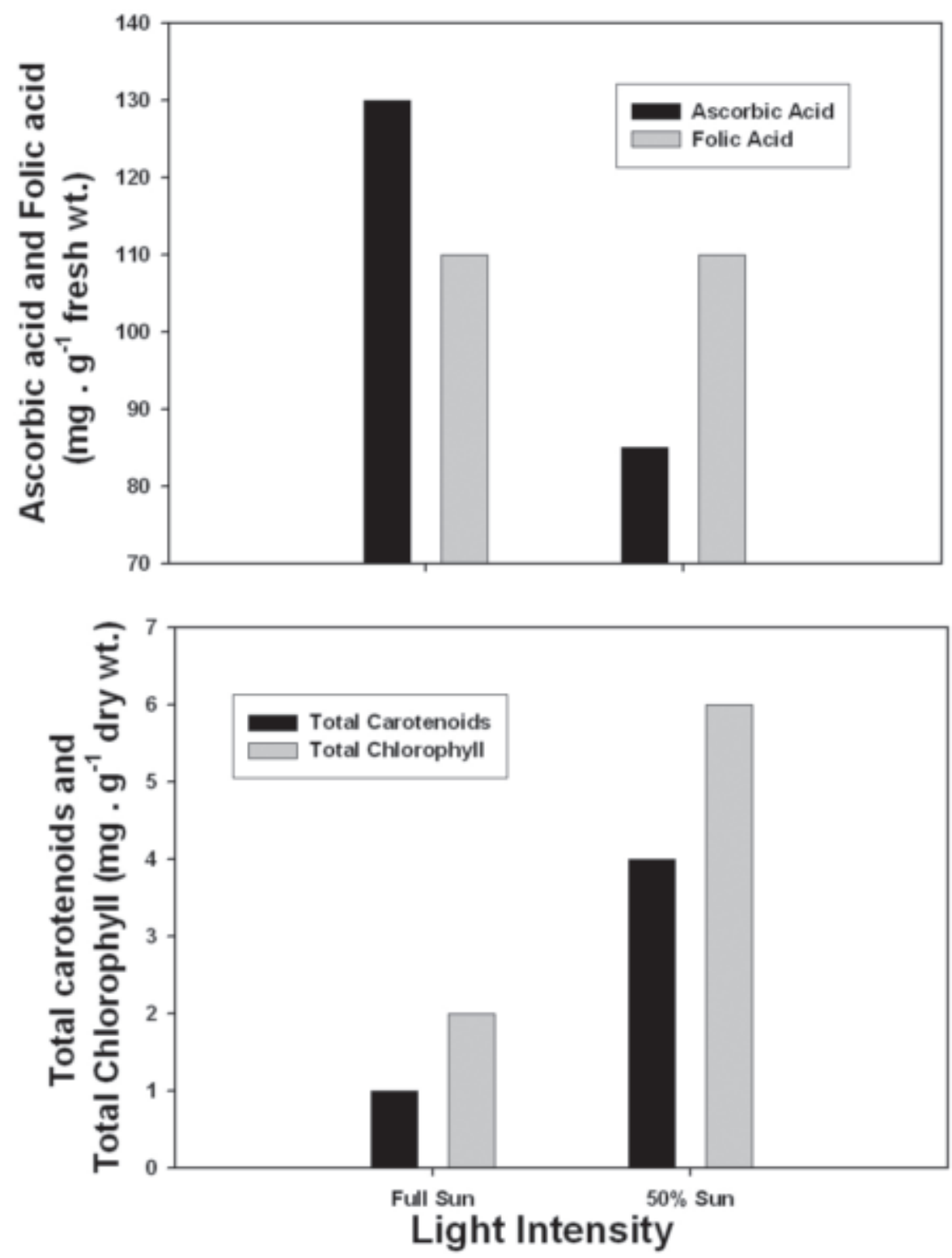

Fig. 4. Effects of growth under full sunlight or $50 \%$ shade on ascorbic acid, folic acid, $\beta$-carotene, and total chlorophyll of mustard greens (Makus and Lester, 2002).

Table 1. Ascorbic acid, $\beta$-carotene, and folic acid concentration in orange-fleshed muskmelon fruit grown on either clay or sandy soil, and the percent difference (Lester and Crosby, 2002; Lester and Eischen, 1996).

\begin{tabular}{lccc}
\hline Soil type & $\begin{array}{c}\text { Ascorbic acid } \\
(\mathrm{mg} / 100 \mathrm{~g} \text { fresh } \mathrm{wt})\end{array}$ & $\begin{array}{c}\beta \text {-Carotene } \\
\left(\mu \mathrm{g} \cdot \mathrm{g}^{-1} \text { fresh } \mathrm{wt}\right)\end{array}$ & $\begin{array}{c}\text { Folic acid } \\
(\mu \mathrm{g} / 100 \mathrm{~g} \text { fresh } \mathrm{wt})\end{array}$ \\
\hline Clay & $20 \mathrm{a}^{z}$ & $20 \mathrm{a}$ & $4 \mathrm{a}$ \\
Sand & $15 \mathrm{~b}$ & $16 \mathrm{~b}$ & $2 \mathrm{~b}$ \\
Difference & $(25 \%)$ & $(20 \%)$ & $(100 \%)$ \\
\hline
\end{tabular}

${ }^{2}$ Means within a column followed by the same letter are not significantly different at $P \leq 0.05$ according to Duncan's. agricultural regions. Apples grown at higher altitudes contain higher ascorbic acid levels (Feteliyer, 1977). At 1000 vs. 50 m, apples contained 2-fold more ascorbic acid due to higher light intensity (140 vs.160 mW), and also likely due to lower temperatures which were not reported. However, apricots grown at higher altitudes contain lower $\beta$-carotene concentrations (Maroutian et al., 1985). At 870 vs. $1250 \mathrm{~m}$ apricot fruit had 2-fold more $\beta$-carotene, due to higher temperatures (20 vs. $12{ }^{\circ} \mathrm{C}$ ). Maximum $\beta$-carotene synthesis in apricots occurs at 15 to $21^{\circ} \mathrm{C}$.

\section{Soil type, pH, and mineral content}

Soil type. Sand, loam, clay, and organic matter content can have a significant effect on the vitamin and mineral concentrations in fruits and vegetables. The likely affect is due to higher mineral concentrations in the more ionic exchangeable soils. Tomatoes grown on sand versus clay had less ascorbic acid (El Mahmoodi et al., 1966). Carrots grown on mineral (clay) versus organic (peat) had more $\beta$-carotene (18 vs. $8 \mathrm{mg} / 100 \mathrm{~g}$ fresh weight, respectively) (Gormley et al., 1971). Melons grown on clay-loam vs. sand-loam had $25 \%$ more ascorbic acid, $20 \%$ more $\beta$-carotene and $100 \%$ more folic acid (Table 1) (Lester and Crosby, 2002; Lester and Eischen, 1996).

Soil $\mathrm{pH}$. Plants grown at their optimal $\mathrm{pH}$ likely will have optimal concentrations of phytonutrients for that crop. Peas grown in increasing soil $\mathrm{pH}$ levels ( $\mathrm{pH} \mathrm{4,} \mathrm{5,} \mathrm{6,} \mathrm{and} \mathrm{7)}$ had increasing levels of $\beta$-carotene of 106 , 112,264 , and $193 \mu \mathrm{g} \cdot \mathrm{g}^{-1}$ dry weight, respectively (Virtanen et al., 1933). Spinach grown at $\mathrm{pH} 4$ versus $\mathrm{pH} 7$ had generally decreasing levels of ascorbic acid (400 vs. $200 \mathrm{~g} / 100 \mathrm{~g}$ dry weight, respectively) (Pfaff and Pfutzer, 1937). In general it can be concluded that plants grown at low or acidic $\mathrm{pH}$ levels will have low carotene concentrations whereas plant grown at high or alkaline $\mathrm{pH}$ levels will have low ascorbic acid concentrations. For additional studies on soil $\mathrm{pH}$ affects on phytonutrients, see Mozafar (1994).

Soil mineral content. The effect of soil minerals on plant vitamins depends on the specific mineral, the mineral form, the phytonutrient, and the plant. The most consistent effects of soil minerals on plant phytonutrients, according to Mozafar (1994), are 1) ascorbic acid decreases with increasing levels of nitrogen; 2) ascorbic acid increases with increasing levels of $\mathrm{P}, \mathrm{K}, \mathrm{Mn}, \mathrm{B}, \mathrm{Mo}, \mathrm{Cu}, \mathrm{Co}$, and $\mathrm{Zn}$; 3 ) $\beta$-carotene increases with increasing levels of $\mathrm{N}, \mathrm{K}, \mathrm{Mg}, \mathrm{Mn}, \mathrm{Cu}, \mathrm{B}$, and $\mathrm{Zn}$; and 4) B-complex vitamins increase with increasing levels of N, P, and B.

Fertilizer: Organic versus mineral. Although limited due to only a few rigorous controlled studies, the literature supports the popular belief that organic (manure) fertilizer is superior to conventional synthetic (mineral) fertilization in achieving a more nutritious fruit or vegetable (Asami et al., 2003). Examples of such studies show that cabbage (Brassica oleracia L.), lettuce (Lactuca spp. L.) and spinach fertilized with manure either alone or in combination with the mineral forms of N, P, 


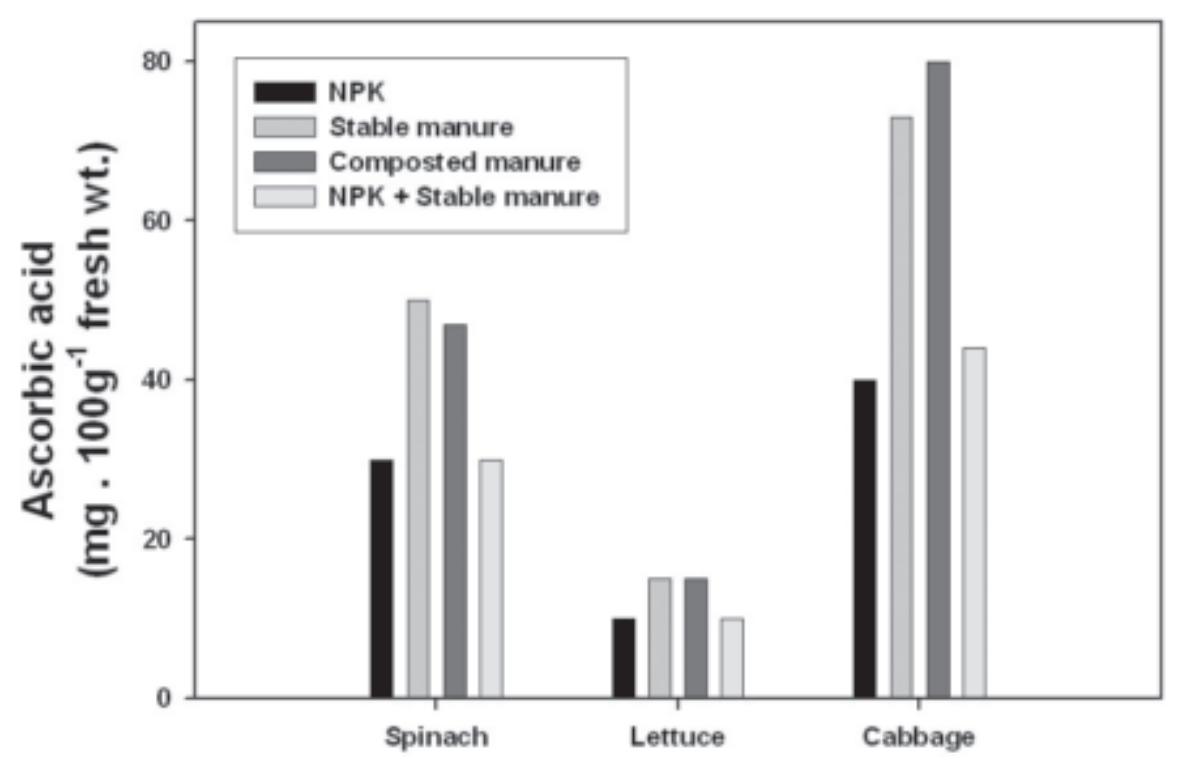

Fig. 5. Effects of mineral, organic, or a combination of mineral and organic fertilizers on ascorbic acid concentration of spinach, lettuce, and cabbage (Schuphan, 1974).

Table 2. Influence of organic vs. conventional production practices on ascorbic acid, $\beta$-carotene, B-complex vitamins, and nitrate nitrogen concentration in carrot roots (Leclearc et al., 1974).

\begin{tabular}{lcc}
\hline Vitamin or & \multicolumn{2}{c}{ Production method } \\
\cline { 2 - 3 } mineral & Conventional & Organic \\
\hline Ascorbic acid $(\mathrm{mg} / 100 \mathrm{~g}$ fresh weight) & 7 & 5 \\
$\beta$-Carotene $(\mathrm{mg} / 100 \mathrm{~g}$ fresh weight) & 36 & 9 \\
Thiamin $(\mu \mathrm{g} / 100 \mathrm{~g}$ fresh weight) & 16 & 43 \\
Riboflavin $(\mu \mathrm{g} / 100 \mathrm{~g}$ fresh weight) & 405 & 17 \\
Niacin $(\mu \mathrm{g} / 100 \mathrm{~g}$ fresh weight) & 178 & 440 \\
Pantothenic acid $(\mu \mathrm{g} / 100 \mathrm{~g}$ fresh weight) & 433 & 180 \\
Nitrate-N $(\mathrm{ppm})$ & & 413 \\
\hline
\end{tabular}

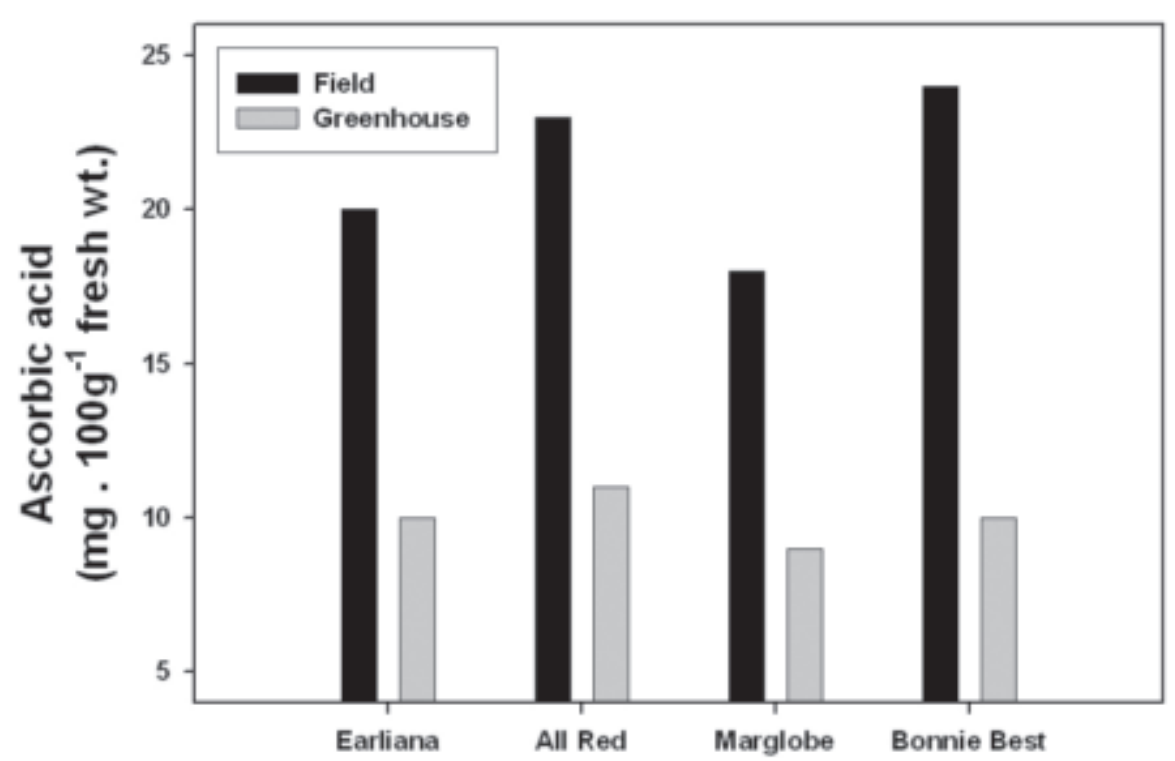

Fig. 6. Effects of greenhouse or field production on ascorbic acid concentration in different tomato varieties (Currence, 1940).

and K had significantly higher levels of ascorbic acid (Fig. 5) (Schuphan, 1974). Also, carrots grown with manure versus mineral fertilizers had higher levels of ascorbic acid, $\beta$-carotene, B-complex vitamins and lower levels of nitrateN (Table 2) (Leclearc et al., 1974).

Greenhouse vs. field production. Greenhouse grown plants, due to the combined effects of higher temperatures and lower light intensities, will have lower levels of most
2) higher temperatures in the greenhouse will lower or inhibit the production of $\beta$-carotene synthesis, especially in cool season plants. For detailed studies see Mozafar (1994).

Irrigation and rainfall. Irrigation or rainfall effects are due primarily to a combination of light and temperature. Rainy, cloudy, cool conditions decrease ascorbic acid and $\beta$-carotene levels in most produce. European black currants (Ribes nigrum L.) grown under sunny, dry conditions (years with 50\% sunny days) versus cloudy, rainy conditions (years with $25 \%$ sunny days) had more than twice the amount of ascorbic acid (247 vs. $110 \mathrm{mg} / 100$ $\mathrm{g}$ fresh weight, respectively) (Shirockenkova et al., 1986). Furrow irrigated lettuce had more ascorbic acid than lettuce irrigated by sprinklers, presumably because the sprinkler system reduced the light intensity (Leclerc et al., 1992). Also, lettuce irrigated by sprinklers had colder leaves, producing 14\% less $\beta$-carotene. Carrots irrigated by a trickle system, achieving soil water holding capacities of $20 \%, 40 \%, 60 \%$, or $80 \%$, at a $30 \mathrm{~cm}$ depth, demonstrated that the least irrigated $(20 \%)$ had $100 \%$ more $\beta$-carotene compared to the most irrigated treatment $(80 \%)$ (Nortje and Henrico, 1986). The difference is due to soil temperature; the $20 \%$ treatment, at a depth of $10 \mathrm{~cm}$, had a soil temperature $5{ }^{\circ} \mathrm{C}$ warmer than the $80 \%$ treatment.

Pests and pollution. Insect and disease pests cause a decrease in all vitamins, especially ascorbic acid, due to altered biosynthesis and translocation (Mozafar, 1994). Pollution from dust, ozone, nitrous oxide, nitrite-N, sulfur dioxide (acid rain), and ammonia have been shown to decrease ascorbic acid, carotenoids, and B-complex vitamins in many fruits and vegetables. The basis for this involves reactive oxygen species. Pollutants, especially oxides, are reactive agents (Hodges, 2003) causing oxidative damage to fruit or vegetable DNA, proteins, synthesizing enzymes, and membranes, therefore altering vitamin biosynthesis and mobilization, and accelerating vitamin loss.

Fruit and vegetable size. Although fruit or vegetable size in and of itself, is not an environmental factor, size has a major impact on the concentration of the available phytonutrients in fruits and vegetables. In lemons [Citrus limon (L.) Burnf.; McDonald and Hildebrand, 1980] and grapefruit (Citrus $\times$ paradisi Macfad.; Aparicio et al., 1990), there exists a negative linear relationship between fruit size and ascorbic acid content.

In general, ascorbic acid decreases with increasing size, whereas carotenoids and Bcomplex vitamins increase with increasing size (Mozafar, 1994). However, the relationship between size and phytonutrient concentration may or may not always be linear; and may not always be negative for ascorbic acid, and positive for carotenoids and B-complex vitamins with increasing size. In muskmelon fruits, ascorbic acid, $\beta$-carotene, and folic acid all increase with increasing fruit size, but medium sized fruit have the highest concentrations compared with smaller or larger fruits (Table 3) (Lester and Crosby, 2002; Lester and Eischen, 
Table 3. Fruit size effect on ascorbic acid, $\beta$-carotene, and folic acid concentration in muskmelons (Lester and Crosby, 2002; Lester and Eischen, 1996).

\begin{tabular}{|c|c|c|c|c|}
\hline \multicolumn{3}{|c|}{ Honey Dew } & \multicolumn{2}{|c|}{ Netted muskmelon } \\
\hline $\begin{array}{l}\text { Fruit size } \\
\text { no. } / 0.03 \mathrm{M}^{3}\end{array}$ & $\begin{array}{c}\text { Ascorbic acid } \\
(\mathrm{mg} / 100 \mathrm{~g} \text { fresh } \mathrm{wt})\end{array}$ & $\begin{array}{c}\text { Folic acid } \\
(\mu \mathrm{g} / 100 \mathrm{~g} \text { fresh } w \mathrm{t})\end{array}$ & $\begin{array}{c}\text { Fruit size } \\
\text { no. } / 0.04 \mathrm{M}^{3}\end{array}$ & $\begin{array}{c}\beta \text {-carotene } \\
\left(\mu \mathrm{g} \cdot \mathrm{g}^{-1} \text { fresh wt }\right)\end{array}$ \\
\hline$\overline{9^{2}}$ & $17 c^{y}$ & $4.0 \mathrm{~d}$ & $23^{2}$ & $16.2 \mathrm{c}$ \\
\hline 8 & $22 \mathrm{~b}$ & $4.8 \mathrm{c}$ & 18 & $17.7 \mathrm{~b}$ \\
\hline 6 & $24 \mathrm{a}$ & $5.2 \mathrm{ab}$ & 15 & $20.8 \mathrm{a}$ \\
\hline 5 & $25 \mathrm{a}$ & $5.4 \mathrm{a}$ & 12 & $21.3 \mathrm{a}$ \\
\hline 4 & $24 \mathrm{a}$ & $5.0 \mathrm{bc}$ & 9 & $16.1 \mathrm{c}$ \\
\hline
\end{tabular}

${ }^{2}$ Number of fruit fitted in to a melon industry standard shipping box.

${ }^{y}$ Means within a column followed by the same letter are not significantly different at $P \leq 0.05$ according to Duncan's.

1996). Both potato (Misra and Chand, 1990) and carrot (Lee, 1986) show a similar response: medium size tubers or roots have the highest vitamin concentrations compared with small or large tubers or roots.

\section{CONCLUSION}

Variability in fruit and vegetable phytonutrient content is inevitable as both genetics and environment influence the rates of synthesis and degradation. Until we can perfectly control nature, and genetically standardize the level of phytonutrients in fruits and vegetables, we will always need to be vigilant in selecting the best genotypes, and the most ideal growing locations to maximize the inherent biosynthesis of plant derived human wellness compounds. Although environmental factors cause large changes in the vitamin content of fruits and vegetables, and control appears largely unmanageable, some management of phytonutrients is possible. Control will occur when growers start growing for phytonutrient content and not solely for yield, and/or appearance. Most of the environmental influences are a combination of temperature, light, fertilization, and pests. Selecting the best possible cultivar, and growing warm or cool season cultivars in their appropriate season, with adequate broad-spectrum light, sufficient water, and well managed production (i.e., soil type, $\mathrm{pH}$, and balanced nutrients), will produce the heartiest/healthiest fruits and vegetables with a high level of human wellness compounds. Broadly and White (2005) in their overview of plant nutritional genomics states that optimizing production inputs during crop production is vital to reducing the use of chemical inputs, thus producing healthier crops with superior levels of phytonutrients and increased pest and disease resistance.

Over time, crop production focused on enhancing the level of phytonutrients, i.e., human wellness compounds in fruits and vegetables, along with consumption of five-a-day or more servings of fruits and vegetables will make for a healthier population and a more productive nation.

\section{Literature Cited}

Alba, R., M.M. Cordonnier-Pratt, and L.H. Pratt. 2000. Fruit-localized phytochromes regulate lycopene accumulation independently of ethylene production in tomato. Plant Physiol. 123:363-370.

Aparicio, J., P.L. Harding, and M.J. Soule, Jr. 1990. a study of grapefruit (Citrus paradisi Macf.) $\mathrm{cv}$.
'Marsh seedless,'physicochemical characterization according to circumference in the Murcia region. Fruits 45:489-495.

Asami, D.K., Y.J. Hong, D.M. Barrett, and A.E. Mitchell. 2003. Comparison of the total phenolic and ascorbic acid content of freeze-dried and air-dried marionberry, strawberry and corn grown using conventional, organic, and sustainable agricultural practices. J. Agr. Food Chem. 51:1237-1241.

Bartley, G.E. and P.A. Scolnik. 1995. Plant carotenoids: Pigments for photoprotection, visual attraction, and human health. Plant Cell 7:1027-1038.

Bradley G.A., D. A. Smittle, A.A. Kattan, and W.A. Sistrunk. 1967. Planting date, irrigation, harvest sequence and varietal effects on carrot yield and quality. Proc. Amer. Soc. Hort. Sci. 90:223-234.

Bottiglieri, T., M. Laundry, R. Crellin, B.K. Toone, M.W. Carney, and E.H. Reynolds. 2000. Homocystine, folate, methylation, and monoamine metabolism in depression. J. Neurol. Neurosurg. Psychol. 69:228-232. genomics. CRC Press Inc., Boca Raton, Fla

Cookson, P.J., J.W. Kiano, C.A. Shipton, P.D. Fraser, S. Romer, W. Schuch, P.M. Bramley, and K.A. Pyke. 2003. Increases in cell elongation, plastid compartment size and phytoene synthase underlie the phenotype of the high pigment- 1 mutant of tomato. Planta 217:896-903.

Cossins, E. 2000. The fascinating world of folate and one-carbon metabolism. Can. J. Bot. 78:691-708

Craig, W. and L. Beck. 1999. Phytochemicals: Health protective effects. Can. J. Dietetic Practice Res. $71: 5-17$

Currence, T.M. 1940. A comparison of tomato varieties for vitamin C content. Proc. Amer. Soc. Hort. Sci. 37:901-906.

Eichholzer, M., J. Luthy, F. Gutzwiller, and H.B. Stahelin. 2001. The role of folate, antioxidant vitamins and other constituents in fruits and vegetables in the prevention of cardiovascular disease: the epidemiological evidence. Intl. J. Vitamin Nutr. Res. 71:5-17.

El Mahmoodi, L.T., M.A. El Shiati, and A.A. Atwa. 1966. Effect of soil type on the keeping quality and storage life of tomatoes. Agr. Res. Rev. (Cairo) 42:82-117.

Feteliyev,E.T. 1977. The effect of altitude on ascorbic acid content. Hort. Abstr. 47:1131.

Gormley, T.R., F. O'Riordain, and M.D. Prendiville. 1971. Some aspects of the quality of carrots on different soil types. J. Food Technol. 6:393-402.

Gross, J. 1991. Pigments in vegetables: Chlorophylls and carotenoids. AVI, Van Nostrand Reinhold, New York

Harris, R.S. 1975. Effects of agricultural practices on the composition of foods, p. 33-57.In: R.S. Harris and E. Karmas. (eds.). Nutritional evaluation of food processing. 2nd ed. AVI, Wesport, Conn.
Broadly, M.R. and P.J. White. 2005. Plant nutritional
Henning, S.M., M.E. Swendseid, and W.F. Coulson. 1997. Male rats fed methyl- and folate-deficient diets with or without niacin develop hepatic carcinomas associated with decreased tissue NAD concentrations and altered poly (ADP-ribse) polymerase activity 1,2. J. Nutr. 127:30-36.

Hodges, D.M. 2003. Postharvest oxidative stress in horticultural crops. The Hawthorn Press, Inc., New York,.

Hyson, D. 2002. The health benefits of fruits and vegetables. A scientific overview for health professionals. Produce for Better Health Foundation, Wilmington, Del

Izumi. H., T. Ito, and Y. Yoshida. 1992. Effect of light intensity during the growing period on ascorbic acid content and its histochemical distribution on the leaves and peel and fruit quality of Satsuma mandarin. J. Jpn. Soc. Hort. Sci. 61:7-15.

Kader, A.A. 1988. Influence of preharvest and postharvest environment on nutritional composition of fruits and vegetables, p. 18-32.In:B. Quebedeaux, and F.A. Bliss (eds.). Horticultural and human health: Contributions of fruits and vegetabels. Proc 1 st Intl. Symp. Horticulture and Human Health. Prentice-Hall, Englewood Cliffs, N.J.

Kalt, W. 2005. Effects of production and processing factors on major fruit and vegetable antioxidants. J Food Sci. 70:R11-19.

Kelly, G.S. 1998. Folates: Supplemental forms and therapeutic applications. Alt. Med. Rev. 3:208-220.

Kiokias, S. and M.H. Gordon. 2004. Antioxidant properties of carotenoids in vitro and in vivo. Food Rev. Intl. 20(2):99-121.

Krumgein, A. and I. Schonohof. 1999. Variation of vitamin $\mathrm{C}$ and secondary compounds in broccoli, p. 346-349. Vitamine und zusatzstoffe in der ernahrung von Mensch und tier. 7th Symp. Jena-Thurigen, Germany.

Larsen, H.R. 1997. Vitamin C: your ultimate health insurance. Intl. J. Alt. Complementary Med. 15:22-24.

Lavine, M. 1986. New concepts in the biology and biochemistry of ascorbic acid. New England J. Med. 314:892-902.

Laclerc, D., A. Wilson, R. Dumas, C. Gafuik, D. Song, D. Watkins, H.H.Q. Heng, J.M. Rommens, S.W. Scherer, D.S. Rosenblat, and R.A. Gravel. 1998. Genetic cloning and mapping of cDNA for methionine synthase reductase, a flavoprotein defective in patients with homocystinuria. Proc. Natl. Acad. Sci. USA 95:3059-3064.

Leclearc, J., M.L. Miller, E. Joliet, and G. Rocquelin. 1974. Vitamin and mineral contents of carrot and celeriac grown under mineral and organic fertilization. Biol. Agr. Hort. 7:339-345.

Leclearc, J., M.L. Miller, E. Joliet, J.P. Thicoipe, and J. Despujols. 1992. The struggle against the death and concentration of minerals and vitamins of Batavia lettuce. Agrochemica 36:108-112.

Lee, C.Y. 1986. Changes in carotenoid content of carrots during growth and postharvest storage. Food Chem. 20:285-293.

Lee, K.S. and A.A. Kader. 2000. Preharvest nd postharvest factors influencing vitamin C content in horticultural crops. Postharv. Biol. Technol. 20:207-220.

Lester, G.E. and F. Eischen. 1996. Beta-carotene content of postharvest orange-fleshed muskmelon fruit: effect of cultivar, growing location and fruit size. Plant Foods Human Nutri. 49:191-197.

Lester, G.E. and K.M. Crosby. 2002. Ascorbic acid, folic acid, and potassium content in postharvest green-flesh honeydew muskmelons: Influence of cultivar, fruit size, soil type and year. J. Amer. Soc. Hort. Sci. 127:843-847.

Lucock, M.D., I. Daskalakis, C.J. Schorah, M.I. Levene, and R. Hartly. 1996. Analysis and biochemistry of blood folate. Biochem. Mol. 
Med. 58:93-112.

Ma. J., M.J. Stampfer, E. Giovannucci, C. Artigas, D.J. Hunter, C. Fuchs, W.C. Willett, J. Selhub, C.H. Hennekens, and R. Rozen. 1997. Methylenetetrahydrofolate reductase polymorphism, dietary interactions, and risk of colorectal cancer. Cancer Res. 57:1098-1102.

Makus, D.J. and G.E. Lester. 2002. Effect of soil type, light intensity and cultivar on leaf nutrients in mustard greens. Subtrop. Plant Sci. 54:23-28.

Maroutian, S.A., V.M. Michaelin, and J.A. Petrossian. 1985. Biochemical changes in apricot trees with vertical zonality. Acta Hort. 192:29-33.

McDonald, R.E. and B.M. Hildebrand. 1980. Physical chemical characteristics of lemons from several countries. J. Amer. Soc. Hort. Sci. 105:135-141.

Misra, J.B. and P. Chand. 1990. Relationship between potato tuber size and chemical composition. J. Food Sci. Technol. 27:63-64.

Mozafar, A. 1994. Plant vitamins: Agronomic, physiological and nutritonal aspects. CRC Press, Boca Raton, Fla.

Nakamoto, H., M. Kuroshima, and K. Shiozawa. 1998. Effects of shading, temperature, watering, application of manure on the oxalate, nitrate, vitamin C contents of spinach. Bul. Hokkaido Pref. Agr. Expt. Sta. 75:25-30.

Nkondjock, A. and P. Ghadirian. 2004. Dietary carotenoids and risk of colon cancer: Case-control study. Intl. J. Cancer 110:110-116.

Nortje, P.F. and J.P. Henrico. 1986. The influence of irrigation interval on crop performance of carrots (Daucus carota) during winter production. Acta Hort. 194:153-158.

Pfaff, C. and G. Pfutzer. 1937. Uber den einfluB der ernahrung auf den carotin- und ascorbinsauregehalt verschiedener germuse- und futterpflanzen. Angewandte Chemie. 50:179-184.

Schuphan, W. 1974. Nutritional value of crops as influenced by organic and inorganic fertilizer treatments: Results of 12 years' experiments with vegetables (1960-1972). Qual. PlantFood Human Nutr. 23(4):333-358.

Sayre, C.B., W.B. Robinson, and T. Wishnetsky. 1953. Effect of temperature on the color, lycopene and carotene content of detached and of vine ripened tomatoes. Proc. Amer. Soc. Hort. Sci. 61:381-387.

Scott, J., F. Rebeille, and J. Fletcher. 2000. Folic acid and folates: The feasibility for nutritional enhancement in plant foods. J. Sci. Food Agr. 80:795-824.

Schmitz-Eiberger, M. and G. Noga. 2001. UV-Bradiation-influence on antioxidative components in Phaseolus vulgaris leaves. J. Appl. Bot. 75:210-215.

Seifried, H.E., S.S. McDonald, D.E. Anderson, P. Greenwald, and J.A. Milner. 2003. The antioxidant conundrum in cancer. Cancer Res.
63:4295-4298.

Shirockenkova, A.I., V.G. Minaeva, and T.A. Zhanaeva. 1986. Activity and iso-enzyme composition of ascorbic acid oxidase and peroxidase in ripening and stored black currents. Hort. Abstr. 56:2277.

Simkin, A., J. Zhu-Changfu, M. Kuntz, and G. Sandman. 2003. Light-dark regulation of carotenoids biosynthesis in pepper (Capsicum annuum). J. Plant Physiol. 160:439-443.

Stevens, M.A. 1974. Varietal influence on nutritional value, p. 87-110. In: P.L. White and N. Selvey (eds.). Nutritional qualities of fresh fruits and vegetables. Futura, Mt. Kisco, N.Y.

Tomes, M.L. 1963. Temprature inhibition of carotene synthesis in tomato. Bot. Gaz. (Chicago). 124:180-185.

Uhlig-Birgit, A. 1998. Effects of solar radiation on grape (Vitis vinifera L.) composition and dried fruit colour. J. Hort. Sci. Biotech. 73:111-123.

Virtanen, A.I., S.V. Hausen, and S. Saastamoinen. 1933. Untersuchungen uber die vitaminbildung in pflanzen. J. Biochem. 267:179-183.

Vogele, A.C. 1937. Effect of environmental factors upon the color of the tomato and watermelon. Plant Physiol. 12:929-955.

Zhi-Qiang, J., D. You-Sheng, J. Zhi-Gou, J. Zq, D. Ys, and J. Zg. 1999. Effects of covering the orchard floor with reflecting films on pigment accumulation and fruit coloration in 'Fuji' apples. Sci. Hort. 82:47-56. 